\title{
PERSEPSI KEPENTINGAN KONTEN PEMBELAJARAN DAN PENGUASAAN APLIKASI DALAM MATAKULIAH SISTEM INFORMASI AKUNTANSI
}

\author{
Rilo Pambudi \\ Weli Imbiri* \\ Almatius Setya Marsudi \\ Unika Atma Jaya, Jalan Jenderal Sudirman 51, Jakarta \\ *weli.imbiri@atmajaya.ac.id
}

\author{
A R T I C L E I N F O \\ Article history: \\ Received January 14, 2020 \\ Revised May 4, 2020 \\ Accepted July 4, 2020
}

Key words:

Konten Pembelajaran, Sistem Informasi Akuntansi, Aplikasi Berbasis Teknologi Informasi

DOI:

https://doi.org/10.33508/jako.v12i2.2310

\begin{abstract}
A B S T R A C T
The purpose of this study is to determine whether there are differences in perceptions between lecturers, students, and companies regarding learning content and mastery of IT-based applications by Accounting students. Data collection was carried out by a survey using a questionnaire to accounting students, accounting teachers, and practitioners in the field of accounting about the importance of mastering IT-based applications and Accounting Information Systems course content for accounting graduates. Data analysis using descriptive analysis, and different tests. A different test is done by looking at the Chi-Square value in the SPSS program. The results show that perceptions of the importance of learning content for student respondents and lecturer respondents vary. While the results of the perception of the importance level of learning content for lecturer respondents and company respondents indicate there are differences for some items. The results for students' mastery of Information Technology applications show that there is a difference in perception about the needs of IT equipment by companies with lecturers on the Spreadsheet application.
\end{abstract}

\begin{abstract}
A B S T R A K
Tujuan dari penelitian ini adalah untuk mengetahui apakah ada perbedaan persepsi antara dosen, mahasiswa dan perusahaan mengenai konten pembelajaran dan penguasaan aplikasi berbasis TI oleh mahasiswa Akuntansi. Pengumpulan data dilakukan dengan survei menggunakan kuesioner kepada mahasiswa akuntansi, pengajar akuntansi, dan praktisi dibidang akuntansi tentang kepentingan penguasaan aplikasi berbasis TI dan konten matakuliah Sistem Informasi Akuntansi bagi lulusan akuntansi. Analisis data menggunakan analisis deskriptif, dan uji beda. Uji beda dilakukan dengan melihat nilai Chi-Square pada program SPSS. Hasil menunjukkan persepsi tingkat kepentingan konten pembelajaran untuk responden mahasiswa dan responden dosen, bervariasi. Sedangkan Hasil persepsi tingkat kepentingan konten pembelajaran untuk responden dosen dan responden perusahaan menunjukkan ada perbedaan untuk beberapa item. Hasil untuk penguasaan mahasiswa terhadap aplikasi Teknologi Informasi menunjukkan adanya ketidak samaan persepsi tentang kebutuhan perangkat TI oleh perusahaan dengan dosen pada aplikasi Spreadsheet.
\end{abstract}

\section{PENDAHULUAN}

Otomatisasi kegiatan bisnis disamping memberi kemudahan juga menciptakan kendala baru khususnya dalam ketersediaan sumber daya manusia yang kompeten dan menguasai perangkat
Teknologi Informasi (TI) seperti aplikasi komputer untuk bisnis, produktivitas dan penggunaan internet. Permintaan penguasaan TI bagi profesi akuntan dalam dunia bisnis semakin meluas (Dai- 
gle dan Morris, 2006), Akuntan diharapkan dapat menguasai perangkat TI dalam tugas mereka. Ketrampilan dalam menggunakan perangkat TI menjadi hal penting bagi lulusan akuntansi apalagi lingkungan bisnis semakin global dan serba dinamis (Darayseh, Waples dan Khaledi, 2008). Fenomena ini memberi tantangan besar bagi dunia pendidikan untuk menyediakan lulusan akuntansi yang dapat menguasai TI dalam mengelola informasi.

Hoffman (2004) menunjukkan bahwa permintaan atas auditor TI semakin meningkat sehubungan dengan adanya regulasi tata kelola TI (IT Governance). Ketrampilan auditor TI harus melebihi auditor tradisional dengan memadukan pengetahuan dan ketrampilan akuntansi dengan TI. Lebih lanjut dinyatakan oleh Kearns (2010), auditor yang kurang dalam pengetahuan TI akan mengalami kesulitan besar dalam mengintegrasikan komputer dalam tugas audit Laporan Keuangan mereka dengan pengetahuan audit professional mereka.

Secara global pentingnya penguasaan perangkat TI oleh lulusan akuntansi telah diatur misalnya oleh American Accounting Association (AAA), dan The International Federation of Accountants (IFAC) jika bekerja sebagai akuntan perusahan. Sedangkan untuk profesi Akuntan Publik (Auditor) di Indonesia telah diatur dalam Standar Profesi Standar Profesional Akuntan Publik (SPAP), dimana seorang akuntan publik harus memiliki pengetahuan memadai tentang sistem informasi berbasis komputer. Bukan hanya sekedar memahami konsep tetapi akuntan diharapkan memiliki kemampuan untuk menggunakan perangkat TI tersebut.

Demi menjawab tantangan tersebut diatas institusi pendidikan harus memastikan kurikulum yang dikembangkan dapat menciptakan akuntan yang kompeten dan sesuai dengan kebutuhan dunia kerja (Kitindi dan Mgaya, 2006). Namun demikian menurut Kitindi dan Mgaya (2006), para pendidik akuntansi semakin tertinggal jauh dari pasar yang kompetitif karena mereka terisolasi dari para professional bisnis. Penelitian Tatikonda (2004) dalam Kitindi dan Mgaya (2006), juga menemukan ketidakpuasan terhadap lulusan akuntansi, karena adanya gap antara kurikulum yang diberikan dengan kebutuhan industri yang semakin berkembang. Temuan ini juga didukung dengan penelitian Harrast, Strong dan Bromley (2010) yang menemukan banyak lulusan akuntansi tidak menguasai TI khususnya penggunaan aplikasi berbasis akuntansi.
Munculnya gap antara permintaan pasar dengan ketersediaan sumberdaya, dimungkinkan karena ketidak konsistenan pada konten mata kuliah Sistem Informasi Akuntansi (SIA) pada berbagai institusi pendidikan dan faktor model atau cara pembelajaran di kelas. Terkait konten SIA, Chayeb dan Best (2005) menjelaskan tidak ada panduan lengkap terkait topik yang harus ada pada matakuliah SIA. Topik yang disampaikan sangat bervariasi dan sangat berbeda satu dengan yang lain. Salah satu penyebab adanya variasi topik SIA adalah ketidakmampuan dan keterbatasan para instruktur dalam mengikuti perkembangan topiktopik terkait TI. Selain itu Albrecht dan Sack (2000), Kearns (2010) dan Macur (1998) menambahkan bahwa instruktur akuntansi kurang memandang penting penguasaan TI bagi karir mahasiswa akuntansi. Banyak program pendidikan akuntansi tidak memasukkan pengetahuan dan ketrampilan TI pada kelas akuntansi manual (konvensional), pengajaran terbatas pada kelas SIA tunggal yang didukung hanya pada matakuliah inti bisnis pada Sistem Informasi Manajemen (SIM). Menurut mereka sangat sedikit yang memandang pentingnya TI pada matakuliah SIA bagi keberhasilan seorang akuntan (auditor).

Selain dari sudut pandang pengajar SIA kesulitan juga dihadapi oleh mahasiswa dalam mengikuti matakuliah SIA. Jackson dan Cherrington (2001) menunjukkan bahwa mahasiswa mengalami kesulitan dalam mengikuti materi matakuliah SIA. Kesulitan yang dialami adalah terkait proyekproyek komputer seperti penggunaan spreadsheet dan software akuntansi yang diintegrasikan pada matakuliah SIA. Peneliti lain, Walters (2011) menemukan mahasiswa memandang materi pembelajaran tentang siklus transaksi bisnis adalah hal yang sulit dipahami dan memerlukan waktu yang cukup lama dan cenderung membosankan.

Berdasarkan uraian di atas dapat disimpulkan bahwa terdapat kesenjangan antara pengetahuan dan ketrampilan yang dimiliki oleh lulusan akuntansi dengan harapan dari dunia kerja (Daigle dan Morris, 2006). Untuk itu penelitian ini akan mengkaji lebih mendalam apakah ada perbedaan persepsi tentang tingkat kepentingan penguasaan perangkat TI oleh mahasiswa akuntansi dan konten pembelajaran dalam matakuliah SIA yang penting dan relevan dengan dunia kerja dibidang akuntansi.

Adapun beberapa rumusan masalah dalam penelitian ini. Rumusan tersebut adalah sebagai berikut: (1) Apakah terdapat perbedaan persepsi tentang pentingnya pemberian konten pembelaja- 
ran dalam matakuliah SIA antara praktisi perusahaan, pengajar akuntansi (instruktur) dan mahasiswa akuntansi?; dan (2) Apakah terdapat perbedaan persepsi tentang penguasaan Aplikasi berbasis TI oleh mahasiswa akuntansi antara praktisi perusahaan dan pengajar akuntansi (instruktur)?.

\section{KAJIAN LITERATUR DAN PENGEMBANGAN HIPOTESIS}

Kajian Literatur

Konten TI dalam Matakuliah SIA

Sistem Informasi dan Teknologi Informasi telah lama diakui sebagai aspek penting dalam bidang studi akuntansi (Jackson dan Cherrington, 2001). Pernyataan ini didukung melalui kurikulum bidang studi akuntansi yang meliputi beberapa matakuliah berbasis komputer, seperti Pengantar Sistem Informasi, Sistem Informasi Manajemen, dan Sistem Informasi Akuntansi (SIA). Namun dari matakuliah-matakuliah tersebut yang berisi konten TI dan akuntansi hanya matakuliah SIA. Dengan demikian diharapkan matakuliah SIA dapat membekali siswa baik dari segi pengetahuan akuntansi maupun kemampuan penggunaan perangkat TI.

Tujuan dari pembelajaran matakuliah SIA adalah mahasiswa mampu memahami konsep proses bisnis berbasis sistem, yaitu mahasiswa berpikir secara logis mulai dari elemen pembentuk sistem sampai dengan prosedur kerja sistem. Hasil akhir yang diharapkan dalam pembelajaran ini adalah mahasiswa mampu menganalisis sistem akuntansi dan memahami implementasi sistem secara praktis dan pada level konseptual bahkan pada level fisik. Pada level konsep sebagaimana dijelaskan dalam Callaghan, Lauer dan Peacock (2011) mahasiswa diharapkan dapat menjelaskan absraksi dari SIA termasuk penggunaan teknik diagram dan konsep pemrograman. Selanjutnya model konseptual tersebut direalisasikan dalam bentuk fisik melalui beberapa jenis peralatan seperti aplikasi spreadsheet, database, paket general ledger, beberapa konsep logika pemrograman. Usulan pemberian konten pembelajaran TI dalam akuntansi disesuaikan dengan peran akuntan sebagai manajer, disainer, dan evaluator sistem. Selain itu konten yang diperlukan dalam pendidikan akuntansi umumnya juga meliputi konsep TI dalam sistem bisnis, pengendalian internal pada lingkungan berbasis komputer, standar dan praktek pengembangan sistem, manajemen adopsi, implementasi dan penggunaan TI, dan evaluasi sistem berbasis komputer.
Pentingnya pengetahuan dan ketrampilan TI telah banyak menjadi perhatian para peneliti sebelumnya. Hasil penelitian Davis (1997) misalnya ditemukan sebanyak $56 \%$ pemberi kerja yang menjadi respondennya menginginkan ketrampilan level menengah (intermediate) dan lanjut (advanced) dalam penguasaan word processing, sebanyak 25\% mengharapkan para lulusan memiliki kemampuan menciptakan, memodifikasi program atau macro, dan lebih dari sepertiganya menginginkan penguasaan database level menengah dan lanjut. Penelitian lain oleh Hunton, Bryant dan Bagranoff (2004), merumuskan pengetahuan dan ketrampilan TI sebagai penguasaan tentang pengetahuan umum TI termasuk didalamnya pemahaman tentang arsitektur database serta software analisis berbasis komputer. Sedangkan menurut Hall dan Singleton (2005), pengetahuan dan ketrampilan TI dasar meliputi penilaian, implementasi, operasi, dan pengendalian sumber daya komputer. Dengan demikian dapat disimpulkan bahwa konten pembelajaran TI sangat penting dimasukkan dalam kurikulum akuntansi.

\section{Pengembangan Hipotesis}

Pandangan Praktisi, Instruktur dan Mahasiswa Terkait SIA

Penelitian tentang konten yang perlu ada pada matakuliah SIA telah banyak dilakukan oleh peneliti-peneliti sebelumnya. Groomer dan Murthy (1996) mendapatkan sebagian pengajar SIA mengalami kesulitan dalam mengajar matakuliah SIA dibandingkan dengan matakuliah akuntansi lainnya. Kesulitan yang ditemui secara khusus terkait materi system akuntansi yang berkaitan dengan komputer yang tersedia dalam textbook SIA. Sedangkan penelitian tentang pendekatan materi yang disampaikan dalam mengajar dilakukan oleh Richtermeyer dan Kovar (2001). Hasil penelitian mereka menunjukkan bahwa mayoritas pengajar menggunakan pendekatan yang beragam, namun sebagian besar materi yang disampaikan adalah siklus transaksi dan proses bisnis menggunakan software akuntansi, spreadsheet, dan database, disamping topik tentang perkembangan TI terkini.

Penelitian terhadap pengajar SIA dilakukan pula oleh Doost, McCombs dan Sharifi (2003), mereka menemukan adanya gap antara permintaan professional dengan kompetensi yang disyaratkan dalam AICPA. Penelitian yang sama juga dilakukan oleh Riner dan Stinson (2004) tentang pandangan pengajar SIA terhadap kurikulum SIA. Sebagian 
besar mereka lebih memprioritaskan pada topik pengendalian internal dan siklus transaksi. Sebagian pengajar tidak memasukkan simulasi berbasis komputer pada matakuliah SIA.

Tribunella, Neely dan Tribunella (2005) melakukan penelitian tentang perbedaan persepsi terhadap topik TI dalam akuntansi antara praktisi dan akademisi. Hasil penelitiannya menunjukkan ada perbedaan persepsi tentang topik TI yang perlu diberikan pada bidang akuntansi. Para praktisi umumnya lebih tertarik pada topik yang berhubungan dengan keamanan dan mobilitas data, tidak terkecuali tentang data mining dan integrasi database yang lebih berguna bagi pengambilan keputusan. Para praktisi tidak fokus pada pengembangan sistem namun lebih pada bagaimana sistem dapat digunakan baik untuk kepentingan strategis maupun untuk keunggulan kompetitif. Sedangkan para akademisi lebih fokus pada kinerja sistem dan pengembangan sistem, terlebih pada isi disain sistem dan sistem jaringan. Selain itu para akademisi lebih tertarik pada sistem yang luas seperti Enterprise Resource Planning (ERP) dan aplikasi ecommerce.

Darayseh, dkk. (2008) melakukan penelitian terhadap lulusan akuntansi terkait penguasaan dan ketrampilan TI dalam kurikulum akuntansi. Hasilnya menunjukkan sebagian besar lulusan akuntansi mengakui pengetahuan komputer sangat penting bagi keberhasilan masa depan mereka. Oleh karena itu mereka menyarankan untuk merevisi kurikulum akuntansi sesuai dengan perkembangan teknologi yang digunakan dalam dunia kerja. Karena menurut mereka sebagian besar kurikulum akuntansi belum mengakomodasi perkembangan dalam teknologi informasi yang ada pada dunia kerja.

Penelitian perbedaan persepsi konten SIA juga dilakukan oleh Dillon dan Kruck (2008), yaitu antara perusahaan konsultan, akuntan publik, dan non konsultan. Hasil penelitian mereka menunjukkan ada perbedaan prioritas konten pembelajaran TI pada matakuliah SIA yang harus dikuasai lulusan akuntansi antara perusahaan non konsultan dengan kantor akuntan publik dan konsultan. Perusahaan non konsultan lebih menekankan pengetahuan yang luas dan ketrampilan yang terintegrasi antara akuntansi dan penguasaan TI serta konsep tentang dunia bisnis. Sedangkan akuntan publik dan konsultan menempatkan prioritas pada pengauditan dan konsep pelaporan keuangan namun demikian perusahaan konsultan lebih menekankan pada konsep TI sedangkan kantor akuntan lebih menekankan pada isu akuntansi.
Namun konten SIA yang paling diprioritaskan oleh ketiga jenis perusahaan adalah penguasaan spreadsheet dan pemahaman siklus akuntansi. Selanjutnya Cory dan Pruske (2012) meneliti tentang pandangan akuntan publik dan non akuntan publik terhadap konten TI dalam kurikulum akuntansi. Hasil penelitian menunjukkan ada 8 (delapan) topik TI yang paling penting bagi lulusan akuntansi yaitu spreadsheet, word processing, creative in problem solving, windows, awareness of ethical issues, internet research, presentation software dan database software. Berbeda dengan penelitian sebelumnya Harrast, dkk. (2010) menunjukkan ada 4 (empat) aplikasi TI yang paling ingin dipelajari oleh mahasiswa akuntansi yaitu tax software, small business accounting systems, generalized audit software, dan spreadsheets. Lebih lanjut dilaporkan bahwa mahasiswa kurang memahami topik terkait ERP dan teknik encryption namun mahasiswa menunjukkan ketertarikan yang moderate terhadap topik flowcharting.

Dengan demikian dapat disimpulkan bahwa konten pada matakuliah SIA yang dipersepsikan penting oleh para instruktur adalah siklus transaksi, proses bisnis, pengendalian internal, pengembangan sistem, kinerja sistem, sistem jaringan, Enterprise Resource Planning (ERP) dan aplikasi e-commerce. Sedangkan aplikasi yang perlu diberikan kepada mahasiswa akuntansi menurut instruktur adalah software akuntansi, spreadsheet, database, serta pengetahuan tentang perkembangan TI terkini.

Sedangkan para praktisi memandang perlu untuk memberikan pengetahuan tentang keamanan dan mobilitas data, data mining, integrasi database, kemampuan menggunakan sistem untuk pengambilan keputusan baik untuk kepentingan strategis maupun untuk mencapai keunggulan kompetitif. Mereka menginginkan mahasiswa memiliki pengetahuan yang mengintegrasikan akuntansi dan penguasaan TI serta konsep tentang dunia bisnis, pengauditan dan konsep pelaporan keuangan. Perangkat TI yang diapndang perlu adalah spreadsheet, word processing, internet, presentation software dan database software.

Sedangkan para lulusan akuntansi memandang topik yang kurang dapat dipahami adalah ERP dan teknik encryption namun yang dipersepsikan penting adalah topik flowcharting. Hasil penelitian terdahulu tersebut mempunyai kesimpulan yang sama tentang perangkat TI yang perlu diberikan ke mahasiswa akuntansi adalah spreadsheets, software akuntansi dan software audit. Sedangkan topik SIA yang dipersepsikan penting 
adalah bisnis proses atau siklus transaksi, disain dan perancangan system serta pengendalian internal yang meliputi isu etis dan keamanan data. Berdasarkan uraian di atas maka hipotesis penelitian dirumuskan sebagai berikut:

H1 : Terdapat perbedaan persepsi tentang pentingnya pemberian konten pembelajaran dalam matakuliah SIA antara praktisi, pengajar akuntansi (instruktur) dan mahasiswa akuntansi

H2 : Terdapat perbedaan persepsi tentang penguasaan Aplikasi berbasis TI oleh mahasiswa akuntansi antara praktisi dan pengajar akuntansi (instruktur)

\section{METODE PENELITIAN}

Definisi Operasional Penelitian

Konten Matakuliah

Konten matakuliah adalah konten pembelajaran yang diberikan dalam matakuliah SIA, terdiri dari 20 konten yaitu: Gambaran Umum Sistem Informasi Akuntansi (SIA): Perspektif Akuntan, Pengantar Siklus Bisnis dan Pengolahan Transaksi, Teknik Dokumentasi Sistem, Etika, Penyimpangan, dan Pengendalian Internal, Teknik Penipuan menggunakan Komputer, Siklus Pendapatan : Penjualan - Penerimaan Kas, Siklus Pengeluaran : Pembelian - Pengeluaran Kas, Siklus Penggajian dan Pengupahan (Human Resources Management), Siklus Aktiva Tetap, Siklus Produksi / Konversi, Sistem Pelaporan: Buku Besar/Sistem Pelaporan Finansial dan Sistem Pelaporan Manajemen, Sistem Pengelolaan Basis Data (Database Management Systems), Pendekatan REA (Resource Event Agent)untuk permodelan Basis Data, Enterprise Resource Planning Systems (ERP), Electronic Commerce Systems (eCommerce), Lingkaran Hidup Pengembangan Sistem (SDLC), Pengendalian di lingkungan Pengolahan Data Berbasis Komputer (IT Control): Sarbanes Oxley dan Tata Kelola IT, Pengendalian di lingkungan Pengolahan Data Berbasis Komputer (IT Control): Keamanan dan Akses, Pengendalian di lingkungan Pengolahan Data Berbasis Komputer (IT Control): Pengembangan Sistem, Perubahan Program Aplikasi, dan Pengendalian Aplikasi, dan Pengauditan Sistem Informasi Berbasis Komputer (IT Audit).

\section{Penguasaan Perangkat TI}

Penguasaan perangkat TI adalah perangkat lunak yang dianggap perlu diberikan kepada mahasiswa yang terdiri dari : Word Processing (MS Word), Spreadsheet (MS Excell), Manajemen Proyek (MS Project), Analisis Statistik (SPSS), Database (MS
Access), Modelling (MS Visio dsb), Presentasi (MS Power Point), Aplikasi Akuntansi (MYOB, Accurate dsb), Aplikasi ERP (SAP, Oracle dsb), Photo Editing, Operating Systems (MS Windows), Communication software, Application Servers, SQL / MySQL, HTML, JAVA, XML, XBRL, Web Services, ASP, Visual Basic, Networking, Technical, System Analyst, Help Desk, Web Development, dan Graphic Design.

\section{Metode Pengumpulan, Pengolahan dan Analisis Data Pengumpulan data}

Pengumpulan data dilakukan dengan survei menggunakan kuesioner kepada mahasiswa akuntansi, pengajar akuntansi, dan praktisi dibidang akuntansi tentang kepentingan penguasaan Aplikasi berbasis TI dan konten matakuliah SIA bagi lulusan akuntansi.

\section{Populasi dan Sampel Penelitian}

Populasi penelitian ini ada 3 (tiga) kelompok, yaitu mahasiswa, dosen pengajar program studi akuntansi dari perguruan tinggi di Jakarta, dan praktisi yang bekerja pada perusahaan manufaktur. Pemilihan sampel dilakukan secara purposive sampling. Pengumpulan data dilakukan dengan dengan mendatangi perguruan tinggi dan perusahaan manufaktur di Jakarta. Setelah mendapatkan ijin dari instansi yang bersangkutan maka kuesioner disebarkan kepada mahasiswa, dosen dan praktisi yang menyatakan diri bersedia untuk berpartisipasi. Teknisnya kuesioner disebar dengan menggunakan aplikasi web Google Drive kepada responden.

\section{Analisis Data}

Analisis data hasil penelitian menggunakan analisis kualitatif deskriptif, dan uji beda dengan melihat nilai Chi-Square pada program SPSS.

\section{HASIL DAN PEMBAHASAN}

\section{Uji Validitas dan Reliabilitas}

Untuk menguji reliabilitas instrument digunakan nilai Cronbach Alpha masing-masing variable. Validitas diuji dengan melihat perbandingan nilai $\mathrm{r}$ hitung dengan nilai $\mathrm{r}$ tabel untuk loading factor masing-masing indikator terhadap variablenya. Nilai Cronbach Alpha skala pengukuran minimal adalah 0,60 (Ghozali, 2011). Sedangkan indikator konstruk dinyatakan valid jika nilai $r$ hitung lebih besar dari $\mathrm{r}$ tabel. Hasil Uji Validitas dan Uji Realibilitas seluruh item pertanyaan menunjukkan nilai Cronbach Alpha lebih dari 0,60 dan seluruh indicator memiliki nilai $\mathrm{r}$ hitung lebih 
besar dari $r$ tabel $(0,070)$, dengan demikian seluruh variabel dapat dinyatakan memenuhi kriteria validitas dan reliabilitas.

\section{Analisis Deskriptif}

Data yang berhasil dikumpulkan dari tiga jenis responden adalah sebagai berikut:

1. Responden mahasiswa berasal dari Program Studi Akuntansi pada Universitas-Universitas di Jakarta yaitu:

Tabel 1. Responden Mahasiswa

\begin{tabular}{|l|l|}
\hline No. & \multicolumn{1}{|c|}{ Nama Universitas } \\
\hline 1. & Unika Atma Jaya Jakarta \\
\hline 2. & Universitas Trisakti \\
\hline 3. & Universitas Tarumanagara \\
\hline 4. & Institut Perbanas, Jakarta \\
\hline 5. & Universitas Pancasila \\
\hline 6. & STIE Trisakti \\
\hline 7. & Universitas Gunadarma \\
\hline
\end{tabular}

Sumber: Data diolah

Penyebaran kuesioner dilakukan sejak April 2014 sampai dengan Juni 2014. Jumlah reponden mahasiswa sebanyak 700 orang dari ketujuh universitas tersebut.

2. Pengumpulan data responden perusahaan dilakukan pada bulan Juni 2014 sampai dengan Agustus 2014. Jumlah responden perusahaan sebanyak 33 perusahaan dari 9 jenis industri tersebut. Industri yang diamati adalah sebagai berikut:

Tabel 2. Jenis Industri Responden

\begin{tabular}{|c|l|}
\hline No. & \multicolumn{1}{|c|}{ Jenis Industri } \\
\hline 1. & Metal \\
\hline 2. & Chemical \\
\hline 3. & Kertas \\
\hline 4. & Otomotif \\
\hline 5. & Tekstil \\
\hline 6. & Kabel \\
\hline 7. & Makanan dan Minuman \\
\hline 8. & Minyak \\
\hline 9. & Farmasi \\
\hline
\end{tabular}

Sumber: Data diolah

3. Pengumpulan data responden pengajar akuntansi dilakukan pada Agustus 2014 sampai dengan November 2014. Jumlah responden dosen akuntansi adalah 134 dosen dari 24 universitas tersebut. Responden pengajar akuntan- si tersebut diperoleh dari beberapa universitas sebagai berikut:

Tabel 3. Responden Pengajar Akuntansi

\begin{tabular}{|c|l|}
\hline No. & \multicolumn{1}{|c|}{ Nama Universitas } \\
\hline 1. & Unika Atma Jaya Jakarta \\
\hline 2. & Universitas Trisakti \\
\hline 3. & Universitas Diponegoro \\
\hline 4. & Institut Perbanas, Jakarta \\
\hline 5. & Universitas Atma Jaya Makassar \\
\hline 6. & Unisbank \\
\hline 7. & STIE Indonesia \\
\hline 8. & Universitas Bina Nusantara \\
\hline 9. & Universitas Moestopo \\
\hline 10. & Universitas Bung Karno \\
\hline 11. & Universitas Mercubuana \\
\hline 12. & Universitas Bunda Mulia \\
\hline 13. & Universitas Tujuh Belas Agustus \\
\hline 14. & Universitas Bakrie \\
\hline 15. & STIE Prasetya Mulya \\
\hline 16. & Universitas Pelita Harapan \\
\hline 17. & Universitas Darma Persada \\
\hline 18. & Universitas Jenderal Soedirman \\
\hline 19. & Unika Soegijapranata \\
\hline 20. & Universitas Widyatama \\
\hline 21. & Universitas Pancasakti Tegal \\
\hline 22. & UIN RIAU \\
\hline 23. & Universitas Bengkulu \\
\hline 24. & STIE Bank BPD Jateng \\
\hline Sumber Data diolah \\
\hline
\end{tabular}

Sumber: Data diolah

Persepsi Kepentingan Konten Pembelajaran Mata Kuliah Sistem Informasi Akuntansi

Berdasarkan hasil analisis tentang variasi persepsi tingkat kepentingan konten pembelajaran untuk responden mahasiswa dan responden dosen didapat pada kolom signifikansi, dimana untuk Konten nomor 1 (Gambaran Umum Sistem Informasi Akuntansi (SIA): Perspektif Akuntan), nomor 2 (Pengantar Siklus Bisnis dan Pengolahan Transaksi), nomor 6 (Siklus Pendapatan: Penjualan-Penerimaan Kas), nomor 7 (Siklus Pengeluaran: Pembelian - Pengeluaran Kas), nomor 8 (Siklus Penggajian dan Pengupahan), nomor 9 (Siklus Aktiva Tetap), nomor 10 (Siklus Produksi/Konversi), nomor 16 (Lingkar Hidup Pengembangan Sistem), nomor 17 (Pengendalian di lingkungan Pengolahan Data Berbasis Komputer (IT Control): Sarbanes Oxley dan Tata Kelola IT ), nomor 19 (Pengendalian di lingkungan Pengolahan Data Berbasis Komputer (IT Control): Pengembangan Sistem, Perubahan Program Aplikasi, dan Pengendalian Aplikasi) dan nomor 20 (Pengauditan Sistem Informasi Berbasis Komputer (IT Audit) baik dosen maupun mahasiswa memiliki persepsi yang berbeda. Hasil yang didapat terkait kon- 
ten pembelajaran mata kuliah SIA menurut persepsi mahasiswa dengan persepsi dosen tersaji sebagai berikut:

Tabel 4. Uji Beda Variasi Konten Mata Kuliah antara Mahasiswa dan Dosen.

\begin{tabular}{|c|c|c|c|c|}
\hline No & Nama Konten Pembelajaran & $\begin{array}{c}\text { Mean } \\
\text { Mahasiswa }\end{array}$ & $\begin{array}{l}\text { Mean } \\
\text { Dosen }\end{array}$ & Sig. \\
\hline 1 & $\begin{array}{l}\text { Gambaran Umum Sistem Informasi } \\
\text { Akuntansi (SIA): Perspektif Akuntan }\end{array}$ & 424,83 & 379,23 & * 0,037 \\
\hline 2 & $\begin{array}{l}\text { Pengantar Siklus Bisnis dan Pengolahan } \\
\text { Transaksi }\end{array}$ & 400,87 & 504,35 & ${ }^{*} 0,000$ \\
\hline 3 & Teknik Dokumentasi Sistem & 421,10 & 398,72 & 0,310 \\
\hline 4 & $\begin{array}{l}\text { Etika, Penyimpangan, dan Pengendali- } \\
\text { an Internal }\end{array}$ & 412,99 & 441,07 & 0,202 \\
\hline 5 & $\begin{array}{l}\text { Teknik Penipuan menggunakan Kom- } \\
\text { puter }\end{array}$ & 410,85 & 452,22 & 0,061 \\
\hline 6 & $\begin{array}{l}\text { Siklus Pendapatan: Penjualan - Pen- } \\
\text { erimaan Kas }\end{array}$ & 424,45 & 381,19 & * 0,049 \\
\hline 7 & $\begin{array}{l}\text { Siklus Pengeluaran: Pembelian - } \\
\text { Pengeluaran Kas }\end{array}$ & 402,62 & 495,22 & * 0,000 \\
\hline 8 & $\begin{array}{l}\text { Siklus Penggajian dan Pengupahan } \\
\text { (Human Resources Management) }\end{array}$ & 405,21 & 481,72 & * 0,001 \\
\hline 9 & Siklus Aktiva Tetap & 407,09 & 471,87 & * 0,003 \\
\hline 10 & Siklus Produksi / Konversi & 404,63 & 484,74 & * 0,000 \\
\hline 11 & $\begin{array}{l}\text { Sistem Pelaporan: Buku Besar/Sistem } \\
\text { Pelaporan Finansial dan Sistem } \\
\text { Pelaporan Manajemen }\end{array}$ & 415,89 & 425,93 & 0,648 \\
\hline 12 & $\begin{array}{l}\text { Sistem Pengelolaan Basis Data (Database } \\
\text { Management Systems) }\end{array}$ & 420,04 & 404,21 & 0,473 \\
\hline 13 & $\begin{array}{l}\text { Pendekatan REA (Resource Event Agent) } \\
\text { untuk permodelan Basis Data }\end{array}$ & 413,53 & 438,25 & 0,264 \\
\hline 14 & $\begin{array}{l}\text { Enterprise Resource Planning Systems } \\
(E R P)\end{array}$ & 408,20 & 466,06 & 0,009 \\
\hline 15 & $\begin{array}{l}\text { Electronic Commerce Systems }(e- \\
\text { Commerce) }\end{array}$ & 413,31 & 439,37 & 0,237 \\
\hline 16 & $\begin{array}{l}\text { Lingkaran Hidup Pengembangan } \\
\text { Sistem }(S D L C)\end{array}$ & 405,19 & 481,79 & * 0,001 \\
\hline 17 & $\begin{array}{l}\text { Pengendalian di lingkungan Pen- } \\
\text { golahan Data Berbasis Komputer (IT } \\
\text { Control): Sarbanes Oxley dan Tata } \\
\text { Kelola IT }\end{array}$ & 404,29 & 486,51 & ${ }^{*} 0,000$ \\
\hline 18 & $\begin{array}{l}\text { Pengendalian di lingkungan Pen- } \\
\text { golahan Data Berbasis Komputer (IT } \\
\text { Control): Keamanan dan Akses }\end{array}$ & 413,01 & 440,94 & 0,207 \\
\hline 19 & $\begin{array}{l}\text { Pengendalian di lingkungan Pen- } \\
\text { golahan Data Berbasis Komputer (IT } \\
\text { Control): Pengembangan Sistem, Peru- } \\
\text { bahan Program Aplikasi, dan Pengen- } \\
\text { dalian Aplikasi }\end{array}$ & 410,37 & 454,77 & * 0,044 \\
\hline 20 & $\begin{array}{l}\text { Pengauditan Sistem Informasi Berbasis } \\
\text { Komputer (IT Audit) }\end{array}$ & 407,77 & 468,34 & * 0,006 \\
\hline \multicolumn{5}{|c|}{$*=$ Signifikan pada $\leq 0,05$} \\
\hline
\end{tabular}

Sumber: Data diolah

Kondisi ini terjadi karena mahasiswa pada umumnya belum memiliki pengetahuan mengenai proses bisnis sebuah perusahaan. Sehingga menjadi tantangan bagi Dosen untuk mempersiapkan konten pembelajaran yang bisa disesuaikan dengan kondisi yang terjadi di perusahaan. Pada saat mempersiapkan konten pembelajaran, setiap dosen perlu melakukan beberapa aksi seperti: Memberikan kegiatan kunjungan ke perusahaan manufaktur, jasa dan dagang. Pada kegiatan tersebut mahasiswa dapat melakukan observasi dan mengerjakan tugas terkait dengan proses bisnis dan proses dokumentasi akuntansi untuk membuat laporan keuangan. Sehingga harapannya mahasiswa dapat memahami konten tersebut yang sesuai dengan keadaan operasional perusahaan saat ini. Hasil yang didapat terkait konten pembelajaran mata kuliah SIA menurut persepsi dosen dengan persepsi perusahaan tersaji dalam tabel 5 .

\section{Tabel 5. Uji Beda Variasi Konten Mata Kuliah antara Dosen dan Perusahaan.}

\begin{tabular}{|c|c|c|c|c|}
\hline No & Keterangan & $\begin{array}{l}\text { Mean } \\
\text { Dosen }\end{array}$ & $\begin{array}{l}\text { Mean } \\
\text { Peru } \\
\text { sahaan }\end{array}$ & Sig. \\
\hline 1 & $\begin{array}{l}\text { Gambaran Umum Sistem In- } \\
\text { formasi Akuntansi (SIA): Per- } \\
\text { spektif Akuntan }\end{array}$ & 82,89 & 88,52 & 0,530 \\
\hline 2 & $\begin{array}{l}\text { Pengantar Siklus Bisnis dan } \\
\text { Pengolahan Transaksi }\end{array}$ & 79,11 & 103,85 & ${ }^{*} 0,006$ \\
\hline 3 & Teknik Dokumentasi Sistem & 80,18 & 99,52 & * 0,034 \\
\hline 4 & $\begin{array}{l}\text { Etika, Penyimpangan, dan } \\
\text { Pengendalian Internal }\end{array}$ & 84,14 & 83,42 & 0,936 \\
\hline 5 & $\begin{array}{l}\text { Teknik Penipuan menggunakan } \\
\text { Komputer }\end{array}$ & 81,82 & 92,85 & 0,214 \\
\hline 6 & $\begin{array}{l}\text { Siklus Pendapatan: Penjualan - } \\
\text { Penerimaan Kas }\end{array}$ & 78,47 & 106,45 & ${ }^{*} 0,002$ \\
\hline 7 & $\begin{array}{l}\text { Siklus Pengeluaran: Pembelian } \\
\text { - Pengeluaran Kas }\end{array}$ & 79,02 & 104,21 & ${ }^{*} 0,005$ \\
\hline 8 & $\begin{array}{l}\text { Siklus Penggajian dan } \\
\text { Pengupahan (Human Resources } \\
\text { Management) }\end{array}$ & 80,60 & 97,79 & 0,056 \\
\hline 9 & Siklus Aktiva Tetap & 80,63 & 97,67 & 0,058 \\
\hline 10 & Siklus Produksi / Konversi & 80,13 & 99,70 & ${ }^{*} 0,030$ \\
\hline 11 & $\begin{array}{l}\text { Sistem Pelaporan: Buku Be- } \\
\text { sar/Sistem Pelaporan Finansial } \\
\text { dan Sistem Pelaporan Mana- } \\
\text { jemen }\end{array}$ & 80,90 & 96,58 & 0,077 \\
\hline 12 & $\begin{array}{l}\text { Sistem Pengelolaan Basis Data } \\
\text { (Database Management Systems) }\end{array}$ & 80,36 & 98,79 & * 0,043 \\
\hline 13 & $\begin{array}{l}\text { Pendekatan REA (Resource Event } \\
\text { Agent) untuk permodelan Basis } \\
\text { Data }\end{array}$ & 83,77 & 84,94 & 0,897 \\
\hline 14 & $\begin{array}{l}\text { Enterprise Resource Planning } \\
\text { Systems (ERP) }\end{array}$ & 82,88 & 88,55 & 0,531 \\
\hline 15 & $\begin{array}{l}\text { Electronic Commerce Systems (e- } \\
\text { Commerce) }\end{array}$ & 84,72 & 81,09 & 0,691 \\
\hline 16 & $\begin{array}{l}\text { Lingkaran Hidup Pengem- } \\
\text { bangan Sistem }(S D L C)\end{array}$ & 83,85 & 84,61 & 0,933 \\
\hline 17 & $\begin{array}{l}\text { Pengendalian di lingkungan } \\
\text { Pengolahan Data Berbasis } \\
\text { Komputer (IT Control): Sarbanes } \\
\text { Oxley dan Tata Kelola IT }\end{array}$ & 87,16 & 71,15 & 0,079 \\
\hline 18 & $\begin{array}{l}\text { Pengendalian di lingkungan } \\
\text { Pengolahan Data Berbasis } \\
\text { Komputer (IT Control): Kea- } \\
\text { manan dan Akses }\end{array}$ & 79,18 & 103,58 & ${ }^{*} 0,007$ \\
\hline 19 & $\begin{array}{l}\text { Pengendalian di lingkungan } \\
\text { Pengolahan Data Berbasis } \\
\text { Komputer (IT Control): } \\
\text { Pengembangan Sistem, Peru- } \\
\text { bahan Program Aplikasi, dan } \\
\text { Pengendalian Aplikasi }\end{array}$ & 81,34 & 94,82 & ${ }^{*} 0,135$ \\
\hline 20 & $\begin{array}{l}\text { Pengauditan Sistem Informasi } \\
\text { Berbasis Komputer (IT Audit) }\end{array}$ & 82,64 & 89,52 & ${ }^{*} 0,445$ \\
\hline \multicolumn{5}{|c|}{$*=$ Signifikan pada $\leq 0,05$} \\
\hline
\end{tabular}

Sumber: Data diolah 
Berdasarkan hasil analisis tentang variasi persepsi tingkat kepentingan konten pembelajaran untuk responden dosen dan responden perusahaan terdapat pada kolom signifikansi, dimana untuk Konten nomor 2 (Pengantar Siklus Bisnis dan Pengolahan Transaksi), nomor 3 (Teknik Dokumentasi Sistem), nomor 6 (Siklus Pendapatan : PenjualanPenerimaan Kas), nomor 7 (Siklus Pengeluaran : Pembelian-Pengeluaran Kas), nomor 10 (Siklus Produksi/Konversi), nomor 12 (Sistem Pengelolaan Basis Data (Database Management Systems)), nomor 18 (Pengendalian di lingkungan Pengolahan Data Berbasis Komputer (IT Control): Keamanan dan Akses), nomor 19 (Pengendalian di lingkungan Pengolahan Data Berbasis Komputer (IT Control): Pengembangan Sistem, Perubahan Program Aplikasi, dan Pengendalian Aplikasi) dan nomor 20 Pengauditan Sistem Informasi Berbasis Komputer (IT Audit) baik dosen maupun Perusahaan memiliki persepsi yang berbeda. Kondisi ini terjadi karena perkembangan dan perubahan yang terjadi di dunia usaha. Perubahan tersebut tidak disesuaikan dengan bahan pembelajaran yang diajarkan di kelas, sehingga berdampak pada mahasiswa. Ketika mereka nanti lulus dan bekerja, mereka akan mempelajari kembali proses bisnis serta proses kerjanya sehingga akan memperlama adaptasi di dalam pekerjaannya nanti. Untuk itu, agar ada kesamaan persepsi antara Dosen dan Perusahaan maka perlu ada kegiatan seperti: Bekerjasama pada perusahaan, berdiskusi konten seperti apa yang perlu dimasukkan dalam materi pembelajaran sesuai sudut pandang perusahaan. Kegiatan lainnya juga bisa bersama-sama menyusun sebuah simulasi bisnis yang dapat dimengerti oleh mahasiswa.

Persepsi Penguasaan Aplikasi Teknologi Informasi Bagi Lulusan Akuntansi

Selanjutnya hasil pengolahan data untuk persepsi tingkat penguasaan Teknologi Informasi yang dipersepsikan oleh perusahaan dan dosen akuntansi bagi lulusan akuntansi dapat dilihat pada Tabel 6.
Tabel 6. Kebutuhan Penguasaan TI oleh Mahasiswa Akuntansi

\begin{tabular}{|c|c|c|c|c|}
\hline \multirow{2}{*}{$\begin{array}{l}\text { Kode } \\
\text { TI }\end{array}$} & \multirow{2}{*}{ Keterangan } & \multicolumn{2}{|c|}{ Mean } & \multirow{2}{*}{ Sig. } \\
\hline & & Dosen & Perusahaan. & \\
\hline TI1 & $\begin{array}{l}\text { Word Pro- } \\
\text { cessing (MS } \\
\text { Word) } \\
\end{array}$ & 85,99 & 79,15 & 0,512 \\
\hline TI2 & $\begin{array}{l}\text { Spreadsheet } \\
\text { (MS Excel) }\end{array}$ & 87,54 & 69,61 & $\begin{array}{l}* \\
0,048\end{array}$ \\
\hline TI3 & $\begin{array}{l}\text { Manajemen } \\
\text { Proyek (MS } \\
\text { Project) }\end{array}$ & 81,34 & 92,56 & 0,228 \\
\hline TI4 & $\begin{array}{l}\text { Analisis Statis- } \\
\text { tik (SPSS) }\end{array}$ & 84,61 & 78,84 & 0,534 \\
\hline TI5 & $\begin{array}{l}\text { Database (MS } \\
\text { Access) }\end{array}$ & 82,16 & 89,09 & 0,456 \\
\hline TI6 & $\begin{array}{l}\text { Modelling (MS } \\
\text { Visio dsb) }\end{array}$ & 82,59 & 87,31 & 0,612 \\
\hline TI7 & $\begin{array}{l}\text { Presentasi (MS } \\
\text { Power Point) }\end{array}$ & 82,93 & 88,33 & 0,559 \\
\hline TI8 & $\begin{array}{l}\text { Aplikasi } \\
\text { Akuntansi } \\
\text { (MYOB, Accu- } \\
\text { rate dsb) }\end{array}$ & 83,46 & 86,21 & 0,765 \\
\hline TI9 & $\begin{array}{l}\text { Aplikasi ERP } \\
\text { (SAP, Oracle } \\
\text { dsb) }\end{array}$ & 82,86 & 86,19 & 0,721 \\
\hline TI10 & Photo Editing & 84,52 & 79,22 & 0,567 \\
\hline TI11 & $\begin{array}{l}\text { Operating Sys- } \\
\text { tems, MS Win- } \\
\text { dows }\end{array}$ & 82,87 & 86,13 & 0,728 \\
\hline TI12 & $\begin{array}{l}\text { Communication } \\
\text { software }\end{array}$ & 86,57 & 70,66 & 0,087 \\
\hline TI13 & $\begin{array}{l}\text { Application } \\
\text { Servers }\end{array}$ & 82,33 & 90,79 & 0,360 \\
\hline TI14 & SQL / MySQL & 84,04 & 81,22 & 0,761 \\
\hline TI15 & HTML & 82,50 & 87,69 & 0,578 \\
\hline TI16 & JAVA & 81,72 & 88,31 & 0,476 \\
\hline TI17 & XML & 82,99 & 85,63 & 0,777 \\
\hline TI18 & XBRL & 84,23 & 80,44 & 0,682 \\
\hline TI19 & Web Services & 84,42 & 77,09 & 0,427 \\
\hline TI20 & ASP & 85,03 & 77,09 & 0,391 \\
\hline $\mathrm{TI} 21$ & Visual Basic & 83,47 & 81,06 & 0,795 \\
\hline TI22 & Networking & 81,47 & 92,00 & 0,258 \\
\hline $\mathrm{TI} 23$ & Technical & 81,87 & 90,31 & 0,364 \\
\hline $\mathrm{TI} 24$ & System Analyst & 83,79 & 84,85 & 0,909 \\
\hline $\mathrm{TI} 25$ & Help Desk & 80,63 & 95,50 & 0,107 \\
\hline TI26 & $\begin{array}{l}\text { Web Develop- } \\
\text { ment }\end{array}$ & 83,13 & 87,52 & 0,635 \\
\hline TI27 & Graphic Design & 84,49 & 79,34 & 0,579 \\
\hline$*=\mathrm{s}$ & ifikan pada & 0,05 & & \\
\hline
\end{tabular}

Sumber: Data diolah

Pada tabel 6 dapat dilihat adanya ketidak samaan persepsi tentang kebutuhan perangkat TI oleh perusahaan dengan dosen pada aplikasi Spreadsheet (MS Excel). Penyebab dari ketidaksa- 
maan persepsi ini adalah kompleksitas data perusahaan yang diolah untuk berbagai keputusan manajemen perusahaan. Sehingga kombinasi rumusan excel yang dibuat sangat banyak. Kombinasi ini tidak dapat diujicobakan ke pengajar sehingga pembelajaran rumusan excel menjadi terbatas pada keilmuan yang ada di pembelajaran kelas. Ketika lulusan akuntansi masuk dunia kerja, mereka terpaksa mempelajari kembali kombinasi rumusan excel kompleks tersebut. Supaya ada kesamaan persepsi terhadap kebutuhan Excel ini, maka yang perlu dilakukan adalah: Pengajar dibekali dengan simulasi-simulasi olahan excel pada setiap jenis usaha perusahaan. Bisa dilakukan semacam workshop, atau mengundang praktisi untuk memberikan pelatihan kepada pengajar atau kepada mahasiswa.

\section{SIMPULAN}

Hasil persepsi tingkat kepentingan konten pembelajaran untuk responden mahasiswa dan responden dosen, dimana untuk Konten nomor 1 (Gambaran Umum Sistem Informasi Akuntansi (SIA): Perspektif Akuntan), nomor 2 (Pengantar Siklus Bisnis dan Pengolahan Transaksi), nomor 6 (Siklus Pendapatan : Penjualan - Penerimaan Kas), nomor 7 (Siklus Pengeluaran : Pembelian - Pengeluaran Kas), nomor 8 (Siklus Penggajian dan Pengupahan), nomor 9 (Siklus Aktiva Tetap), nomor 10 (Siklus Produksi/ Konversi), nomor 16 (Lingkar Hidup Pengembangan Sistem), nomor 17 (Pengendalian di lingkungan Pengolahan Data Berbasis Komputer/ IT Control: Sarbanes Oxley dan Tata Kelola IT), nomor 19 (Pengendalian di lingkungan Pengolahan Data Berbasis Komputer/ IT Control: Pengembangan Sistem, Perubahan Program Aplikasi, dan Pengendalian Aplikasi) dan nomor 20 (Pengauditan Sistem Informasi Berbasis Komputer/ IT Audit) memiliki persepsi yang berbeda. Sehingga untuk menyamakan persepsi tersebut perlu melakukan beberapa aksi seperti: Memberikan kegiatan kunjungan ke perusahaan manufaktur, jasa dan dagang. Pada kegiatan tersebut mahasiswa dapat melakukan observasi dan mengerjakan tugas terkait dengan proses bisnis dan proses dokumentasi akuntansi untuk membuat laporan keuangan. Sehingga harapannya mahasiswa dapat memahami konten tersebut yang sesuai dengan keadaan operasional perusahaan saat ini.

Sedangkan Hasil persepsi tingkat kepentingan konten pembelajaran untuk responden dosen dan responden perusahaan untuk konten nomor 2 (Pengantar Siklus Bisnis dan Pengolahan Transaksi), nomor 3 (Teknik Dokumentasi Sistem), nomor 6 (Siklus Pendapatan : Penjualan - Penerimaan Kas), nomor 7 (Siklus Pengeluaran : Pembelian - Pengeluaran Kas), nomor 10 (Siklus Produksi/ Konversi), nomor 12 (Sistem Pengelolaan Basis Data/ Database Management Systems), nomor 18 (Pengendalian di lingkungan Pengolahan Data Berbasis Komputer/ IT Control: Keamanan dan Akses), nomor 19 (Pengendalian di lingkungan Pengolahan Data Berbasis Komputer/ IT Control: Pengembangan Sistem, Perubahan Program Aplikasi, dan Pengendalian Aplikasi) dan nomor 20 (Pengauditan Sistem Informasi Berbasis Komputer/ IT Audit) memiliki persepsi yang berbeda. Sehingga untuk menyamakan persepsi tersebut maka perlu ada kegiatan seperti: Bekerjasama pada perusahaan, berdiskusi konten yang perlu dimasukkan dalam materi pembelajaran sesuai sudut pandang perusahaan. Kegiatan lainnya juga bisa bersama-sama menyusun sebuah simulasi bisnis yang dapat dimengerti oleh mahasiswa.

Hasil penguasaan mahasiswa terhadap aplikasi Teknologi Informasi menunjukkan adanya ketidak samaan persepsi tentang kebutuhan perangkat TI oleh perusahaan dengan dosen pada aplikasi Spreadsheet (MS Excel). Supaya ada kesamaan persepsi terhadap kebutuhan Excel ini, maka yang perlu dilakukan adalah: Pengajar dibekali dengan simulasi-simulasi olahan excel pada setiap jenis usaha perusahaan. Bisa dilakukan semacam workshop, atau mengundang praktisi untuk memberikan pelatihan kepada pengajar atau kepada mahasiswa.

Populasi terbentuk dalam penelitian ini hanya berlokasi di Jabodetabek untuk Mahasiswa dan Perusahaan. Sedangkan untuk Dosen belum tersebar merata. Sehingga ini mejadi keterbatasan dalam penelitian ini sehingga saran dalam penelitian selanjutnya adalah: Mengembangkan populasi untuk mahasiswa dan perusahaan di area Jawa, Sumatra atau propinsi lainnya. Untuk dosen, bisa dikembangkan ke Indonesia Timur.Untuk konten pembelajaran juga bisa dikembangkan dengan membahas peran Akuntan dalam perubahan Teknologi Informasi di dalam perusahaan.

\section{REFFERENCES}

Albrecht, W. S. dan Sack, R. J. (2000). Accounting Education: Charting the Course through a Perilous. Accounting Education Series, 16, 1-72. 
Callaghan, J. H., Lauer, T. W. dan Peacock, E. (1998). Developing A Comprehensive Curriculum For Accounting In-formation Systems: A Model-Oriented, Tool-Enhanced Approach. Review of Business Information Systems (RBIS), 2(4), 57-66.

Chayeb, L. dan Best, P. J. (2005). The Accounting Information Systems Curriculum: Compliance with IFAC Requirements. Prosiding. International Conference on Innovation in Accounting Teaching \& Learning: Hobart.

Cory, S. N. dan Pruske, K. A. (2012). Necessary Skills for Accounting Graduates: An Explorattory Study to Determine What the Profession Wants. Prosiding. ASBBS Annual Conference: Las Vegas.

Daigle, R. J. dan Morris, P. W. (2006). Fear Factor: The AIS Course and Non-Positive Attitudes Towards Computers. Review of Business Information Systems (RBIS), 10(1), 11-26.

Darayseh, M., Waples, E. dan Khaledi, N. (2008). The Impact of the Acceleration of Information Technology on the Content of the Accounting Courses: The Case of GCC. Review of Business Information Systems (RBIS), 12(3), 89-96.

Davis, P. (1997) What Computer Skills Do Employers Expect from Recent College Graduates?. THE Journal, 25(2), 74-78.

Dillon, T. W. dan Kruck, S. E. (2008). Identifying Employer Needs from Accounting Information Systems Programs. Journal of Information Systems Education, 19(4), 403-410.

Doost, R. K., McCombs, G. B. dan Sharifi, M. (2003). The State Of Teaching Accounting Information Systems: Is There A Gap?. Review of Business Information Systems (RBIS), 7(3), 6170.

Ghozali, I. (2011). Aplikasi Analisis Multivariate Dengan Program SPSS. Semarang: Badan Penerbit Universitas Diponegoro.

Groomer, S., dan Murthy, U. (1996). An empirical analysis of the accounting information systems course. Journal of Information Systems, 10(2).

Hall, J. A. dan Singleton, T. (2005) Information Technology Auditing and Assurance. Ohio: Thomson South-Western.

Harrast, S., Strong, J. dan Bromley, R. (2010). More Accounting Theory or More Information Technology?. The Accounting Educators' Journal, 20(1), 1-19.

Hoffman, T. (2004). IT Auditors Coveted, Hard to Find.

Didapat

dari https://www.computerworld.com/article/2

564776/it-auditors-coveted--hard-tofind.html, 02 Maret 2014, pukul 14.50 WIB.

Hunton, J. E., Bryant, S. M. dan Bagranoff, N, A. (2004). Core Concepts of Information Technology Auditing. Boston: Wiley and Sons.

Jackson, R. B. dan Cherrington, J. O. (2001). IT instruction methodology and minimum competency for accounting students. Journal of Information Systems Education, 12(4), 213-222.

Kearns, G. S. (2010). Measuring AIS Course Outcomes: The Relationship Between Knowledge/Skills and Interest/Enjoyment. AIS Educator Journal, 5(1), 47-69.

Kitindi, E. G. dan Mgaya, V. K. (2006) Esential skills for accounting graduates: the accounting practitioner's pespective. African Journal of Finance and Management, 15(1), 31-47.

Macur, K. M. (1998). The Curricular Content of Accounting Information Systems. Review of Business Information Systems (RBIS), 2(3), 1120.

Richtermeyer, S. B. dan Kovar, S. E. (2001). AIS Education: Incorporating Trends in Technology into the Curriculum. Review of Business Information Systems (RBIS), 5(4), 1-12.

Riner, H. S. dan Stinson, T. A. (2004). A Study Of Curriculum Issues Related To Teaching Accounting Information Systems. Review of Business Information Systems (RBIS), 8(1), 4752.

Tribunella, T. J., Neely, M. P. dan Tribunella, H. R. (2005). Academic and Practitioner Interests Regarding Emerging Technologies in Accounting. Journal of College Teaching and Learning, 2(5), 31-42.

Walters, M. (2011). An Imaginative Exercise for Teaching Transaction Cycles in an AIS Course. AIS Educator Journal, 6(1), 1-10. 